\title{
Тихомиров А. А. «Лучший друг немецкого народа»: культ Сталина в Восточной Германии (1945-1961 гг.). М.: РОССПЭН, 2014. 310 c.
}

\begin{abstract}
Аннотаиия. Речензия представляет собой критический анализ новейшего исследования А. А. Тихомирова, посвященного культу Сталина в Восточной Германии в период становления партийных и государственных структур. Автор рецензии отмечает, что монография является достойным вкладом в актуальные дискуссии о транснаииональном измерении истории позднего сталинизма, в реконструкиию символических механизмов освоения периферии советской империи, изучение особенностей функционирования «диктатуры дискурса» и (само)сотворения “суббекта диктатуры». Ключевыми пунктами анализа являются спечифика сотворения символического пространства сталинизма в Центральной и Восточной Европе, его гомогенизачия и герметизаиия, а также роль государственных, групповых и индивидуальных акторов. Значимыми выводами автора являются замечания о решающей роли «поколения патриархов», длительное время проживиих в советской эмиграчии, досконально изучивших правила советских дискурсивных игр и стремившихся их соблюдать во имя укрепления и сохранения собственной власти, о взаимовыгодности создания конструкиий подчинения периферии иентру империи. Критике со сторонъ речензента подвергаются: часть аргументаиии автора, основанная на привлечении изначально идеологизированных материалов западногерманской СДПГ, несбалансированность наииональной и трансначиональной перспектив. Подчеркивая значимость авторского вклада в решение научной проблемы, речензент обозначает возможные перспективы его продолжения в развернутом анализе конкурениии имперских периферий друг с другом перед Москвой в вопросах правильной символизаиии культового сообщества.
\end{abstract}

Ключевые слова: новая политическая история, визуальная антропология, история ГДР, история СССР, СВАГ, СЕПГ, культ Сталина, культурный трансфер, поколение патриархов, субъект диктатуры.

Abstract. This review presents a critical analysis of A. A. Tikhomirov's newest study dedicated to the cult of Stalin in Eastern Germany during the formation period of party and government structures. The review's author notes that the monograph is a worthy contribution to the current discussions regarding the transnational measurement of late Stalinism history, to the reconstruction of the peripheries of the Soviet empire's symbolic mechanisms of assimilation, and to the study of the working specifics of the "discourse dictatorship" and (self)creation of "dictatorial subject". The key points of the analysis are the specifics behind the creation of Stalinist symbolic space in Central and Eastern Europe, its homogenisation and encapsulation, as well as the role of government, group, and individual actors. The most significant conclusions the author comes to are his comments on the decisive role of the "patriarch generation", which lived for a long time in Soviet emigration and thoroughly studied the rules of the Soviet discourse games and sought to follow them for securing and strengthening their own power, and on the mutual beneficial creation of a structure to subordinate the peripheries to the centre of the empire. The reviewer criticises the part of the author's argument that is based on initially ideologised materials of the West German Social Democratic Party of Germany, logical contradictions, and unbalanced national and transnational perspectives. Valuating positively the book author's research overall, the reviewer notes possible direction for its continuation as a detailed analysis of the competition of the imperial peripheries between themselves before of Moscow regarding questions of the correct symbolisation of the cult community.

Key words: new political history, visual anthropology, history of GDR, history of USSR, SMAG, SUPG, cult of Stalin, cultural transfer, generation of patriarchs, dictatorial subject.

еханизмы конструирования авторитарного субъекта, факторы устойчивости современных диктатур, степень восприятия населе- нием транслируемых «сверху» политических идеологем на протяжении многих лет являются предметом оживленных дискуссий среди исследователей сталинизма. Слабо изученным 


\section{Рецензии, библиография}

DOI: $10.7256 / 2222-1972.2015 .5 .17284$

до сих пор оставалось транснациональное измерение - специфика процесса циркуляции дискурсивных конструкций и политических практик внутри оформившейся по окончании Второй мировой войны позднесталинской советской империи [1]. Именно комплексному анализу истории создания, трансформации и деконструкции культа Сталина в ранней ГДР (1945-1961 гг.) посвящена работа А. Тихомирова. В ракурсе междисциплинарного подхода новой политической истории автор ставит своей целью реконструкцию символических механизмов освоения периферии советской империи, изучение особенностей функционирования «диктатуры дискурса» и (само)сотворения «субъекта диктатуры».

Стремясь объединить в своей работе два уровня анализа - перспективу репрезентаций «сверху» и их восприятия «снизу», - автор опирается на достаточно широкую источниковую базу - партийные документы СЕПГ и КПСС, отчеты СВАГ и Штази, мемуары и визуальные материалы. Достаточно спорной группой источников представляются привлеченные к анализу документы западногерманской СДПГ. Используемые автором с целью «избежать биполярных оценок жизни субъекта в диктатуре», они чаще всего цитируются как подтверждение неудач советской и восточногерманской пропаганды, уклонения населения от индоктринации и массовости протестных настроений.

Решающую роль в формировании культа Сталина в Восточной Германии автор приписывает так называемому поколению патриархов деятелей КПГ, длительное время проживших в советской эмиграции, досконально изучивших правила советских дискурсивных игр и после возвращения на родину стремившихся их соблюдать во имя укрепления и сохранения собственной власти. Неслучайно образ Сталина в ГДР инициирует возникновение сложной иерархии культов, на нижнем уровне которой оказываются образы представителей немецкого партийного руководства. Автор книги подчеркивает взаимовыгодность создания конструкций подобного рода подчинения периферии центру империи: такие конструкции гарантировали руководству ГДР получение жизненно важной экономической и политической поддержки Москвы. Именно благодаря «патриархам», сыгравшим роль канала трансфера, поклонение Сталину переросло в 1948 г. рамки внутрипартийного мероприятия и превратилось в один из центральных столпов политической культуры «первого немецкого государства рабочих и крестьян».

Ключевым пунктом авторского анализа является изучение сотворения символического пространства сталинизма в Центральной и Восточной Европе, его гомогенизации и герметизации, а также роли государственных, групповых и индивидуальных акторов. На оккупированных территориях Восточной Германии идеологам «культа Сталина» пришлось противостоять укорененному нацистской диктатурой образу «красного дьявола»и трансформировать его в устойчивое представление о Сталине как «лучшем друге немецкого народа». Автор детально исследует многогранные механизмы «диктатуры дискурса»: монополизацию производства репрезентаций, стабилизацию политической коммуникации через жесткий контроль публичных сфер, символическую оккупацию, карательную политику по отношению к нарушителям установленных риторических границ, наконец, рутинизацию власти, которая приводит к стабилизации и самовоспроизводству авторитарного режима. Наглядными иллюстрациями апогея культа Сталина в Восточной Германии стали его символические воплощения в берлинской Сталиналлее, Сталинштадте, юбилейных торжествах к 70-летию вождя. Примечательно, что и смерть Сталина использовалась властями ГДР как инсценировка общественного консенсуса.

Все же реализация столь масштабного и сложного проекта не была избавлена от сбоев и перекосов, далеко не всегда приводила к желаемому результату. Так, советская сторона при навязывании собственных образцов визуальной пропаганды не всегда учитывала немецкую специфику, гомогенность дискурса нарушалась в приграничных территориях, население которых могло наблюдать альтернативную действительность, культ советского вождя налагался на инерцию культа фюрера и т. д. Тем не менее выстраивание культа Сталина в Восточной Германии являлось для населения по-своему рациональной стратегией выживания в условиях послевоенного краха, обещая стабилизацию общественного порядка и продовольственного снабжения. Желательным, с точки зрения читателя, однако, является расширение числа репрезентативных примеров, в частности, более емких иллюстраций использования культа Сталина в целях социальной мимикрии функционерами прежнего режима (создается впечатление, что все они действительно выехали на Запад). 


\section{Исторический журнал: научные исследования № 5 (29) • 2015}

DOI: 10.7256/2222-1972.2015.5.17284

Одним из ключевых инструментов навязывания культа явилась эмоциональная составляющая - использование коллективного чувства вины немцев за последствия Второй мировой войны и нанесенный Советскому Союзу хозяйственный и демографический ущерб. В этих целях, по мнению Тихомирова, образ Сталина-победителя как символ морального унижения стремительно сменяется образом всепрощающего друга, благодарность которому освобождала от тяжкого исторического бремени все население Восточной Германии. Однако, как представляется в свете актуальных работ, столь прямолинейные авторские конструкции выглядят известным упрощением и требуют дополнительной проблематизации: каким образом предложение освобождения восточных немцев от коллективного чувства вины было реализовано различными поколенческими и опытными сообществами [2, 220-221], была ли динамика этих процессов на самом деле столь стремительна и равномерна $[3,200-210]$ ?

Логичным завершением анализа жизненного цикла культа вождя становится процесс его деконструкции. Тихомиров расценивает преждевременные шаги В. Ульбрихта по инициированию обсуждения ошибок величины, считавшейся ранее непогрешимой, как логическое развитие «диктатуры дискурса» и попытку восточногерманского лидера превентивно защитить собственные властные позиции. Однако несогласованность шагов и отсутствие прямых распоряжений из Москвы привели к неконтролируемости смещения дискурсивных границ и противоречивым реакциям со стороны членов партии: открытому отторжению десталинизации, страху и попыткам отмолчаться, общему недоверию по отношению к руководству СЕПГ. Трансформация культа спровоцировала открытое обсуждение тех межгосударственных проблем в социалистическом лагере, которые ранее замалчивались, например, вопроса о правомерности послевоенных границ в Восточной Европе. В то же время она привела к примирению восточных немцев с националсоциалистическим прошлым, замещению воз- никших лакун пропагандистского визуального пространства культом Ленина, национальных классиков марксизма и деятелей революции. Рубежом десталинизации в ГДР стало венгерское восстание 1956 г., которое привело к радикализации «иконоборческих» практик и ответному переходу государственных ведомств к жестким мерам контроля.

Поставив перед собой масштабные исследовательские задачи, большинство из которых успешно решаются в ходе повествования, автор тем не менее допускает логические противоречия. Подчеркивая в постановочной части книги феномен укорененности в послевоенном немецком обществе паролей национал-социалистической идеологии, культа Гитлера и в целом сложность перехода от одной диктатуре к другой (с. 5-7), автор в середине работы противоречит сам себе, утверждая, что социалистической пропаганде приходилось подстраиваться в Восточной Германии «под западное общество индивидов и индивидуальностей» (с. 153). Критикуя во вводной части книги распространенную среди современных немецких исследователей истории ГДР «модель <...> представления западного либерального субъекта» как «однобокую» попытку постфактум компенсировать «отсутствие широкого сопротивления в Третьем рейхе <...> показав критическое коллективное дистанцирование» от «диктатуры СЕПГ» (с. 25-26), Тихомиров при анализе реакций населения на транслируемый «сверху» культ по сути дела пользуется исключительно наработанными этим направлением аналитическими конструкциями (Eigensinn), не предлагая радикально нового понятийного аппарата и инструментария.

Дискуссионные моменты представленного исследования не препятствуют, однако, общей оценки книги как новаторского вклада в актуальные исследования транснационального измерения истории позднего сталинизма. Возможной перспективой изучения видится анализ конкуренции имперских периферий друг с другом перед Москвой в вопросах правильной символизации культового сообщества.

\section{Библиография:}

1. Alexej Tikhomirov. "Luchschij drug nemezkogo naroda": Kult Stalina v Vostochnoj Germanii ("Der beste Freund des deutschen Volkes": Stalin-Kult im Ostdeutschland (1945-1961). Moskau: ROSSPEN, 2014, 310 S. / Reviewed by Oksana Nagornaja // Jahrbücher für Geschichte Osteuropas. 2015. № 3. [В печати].

2. Satjukow S. "Zeitzeugen der ersten Stunde": Erinnerungen an den Nationalsozialismus in der DDR // Die Geburt der Zeitzeugen nach 1945 / Hrsg. von M. Sabrow, N. Frei. Berlin: Wallstein-Verl., 2012. S. 201-223. 


\section{Рецензии, библиография}

DOI: $10.7256 / 2222-1972.2015 .5 .17284$

3. Нагорная О. «Поколение» и «память» в транснациональном пространстве советских вузов: восточногерманские студенты в СССР // «Работа над прошлым»: XX век в коммуникации и памяти послевоенных поколений Германии и России / Под ред. О. С. Нагорной и др. Челябинск: Каменный пояс, 2014. С. 200-210.

4. Трушкина Е. Ю. Антропология визуальной коммуникации: история и методология // Человек и культура. 2014. № 6. C. 29-43. DOI: 10.7256/2409-8744.2014.6.14764. URL: http://www.e-notabene.ru/ca/article_14764.html

\section{References (transliterated):}

1. Alexej Tikhomirov. "Luchschij drug nemezkogo naroda”: Kult Stalina v Vostochnoj Germanii ("Der beste Freund des deutschen Volkes": Stalin-Kult im Ostdeutschland (1945-1961). Moskau: ROSSPEN, 2014, 310 S. / Reviewed by Oksana Nagornaja // Jahrbücher für Geschichte Osteuropas. 2015. № 3. [V pechati].

2. Satjukow S. "Zeitzeugen der ersten Stunde": Erinnerungen an den Nationalsozialismus in der DDR // Die Geburt der Zeitzeugen nach 1945 / Hrsg. von M. Sabrow, N. Frei. Berlin: Wallstein-Verl., 2012. S. 201-223.

3. Nagornaya 0. «Pokolenie» $\mathrm{i}$ «pamyat'» v transnatsional'nom prostranstve sovetskikh vuzov: vostochnogermanskie studenty v SSSR // «Rabota nad proshlym»: KhKh vek v kommunikatsii i pamyati poslevoennykh pokolenii Germanii i Rossii / Pod red. O. S. Nagornoi i dr. Chelyabinsk: Kamennyi poyas, 2014. S. 200-210.

4. Trushkina E. Yu. Antropologiya vizual'noi kommunikatsii: istoriya i metodologiya // Chelovek i kul'tura. 2014. № 6. S. 29-43. DOI: 10.7256/2409-8744.2014.6.14764. URL: http://www.e-notabene.ru/ca/article_14764.html 